\title{
Determinants of Capital Structure in Industrial Companies: Conservative Policy_Applied Study on Jordanian Industrial for the Period (2014-2016)
}

\author{
Abeer Al Abbadi ${ }^{1}$ \\ ${ }^{1}$ Department of Finance and Banking, Faculty of Business and Finance, The World Islamic Sciences and \\ Education University, Jordan \\ Correspondence: Abeer Al Abbadi, Department of Finance and Banking, Faculty of Business and Finance, The \\ World Islamic Sciences and Education University, Jordan. E-mail: abeer_abadei@yahoo.com
}

Received: April 29, 2018

Accepted: November 16, 2018

Online Published: January 25, 2019

doi:10.5539/ijbm.v14n2p125

URL: https://doi.org/10.5539/ijbm.v14n2p125

\begin{abstract}
The study aimed to define the factors that determinate the capital structure for industrial companies in Jordan. By depending on theoretical references and literature review that related to capital structure, and to define the determinants that influenced the capital structure by depending on statistical analysis. The study used 15 companies of Amman stock exchange for the period 2014-2016.

The study concluded multiple results. The most importantly, there is significant impact of profitability, interest rates, and the amount of tangible assets. And there is impact of investment opportunities, the size of company and to the adoption of conservative policy according to the comprehensive concept of indebtedness in building capital structure. There was no possible impact for financial distress. The study proposed recommendations. The most important recommendations are studying the underlying causes of reduction long term debt ratio to the total assets of many public share holding companies. Urging financial managers to study the capital structure and the factors that determinate it, in order to manage the capital structure of the companies according to scientific methodology. Urging companies to use Islamic instruments for funding the tangible assets .As it is appropriate to the prevailing economic conditions in the market in terms of profit rates. It is necessary to confirm the existence of a credit rating classification from international credit agencies that helps in issuance of instruments and corporate bonds, or to obtain credit. Urging companies using rent ending in ownership or finance leasing; and urging companies of tangible assets to obtain funding from Islamic and commercial banks especially, when the cost of borrowing and Islamic funding is less than the cost of the issuance of shares. The study suggested studying the determinate factors that makes some companies following the conservative policy in building the capital structure, and in maintaining high cash balances. The study affected the impact of the existence of financial organizations as board of directors in public shareholding companies determine and study the factors of building the capital structure.
\end{abstract}

Keywords: Leverage, determinants, capital structure, industrial sector, Jordan, conservative policy

\section{Introduction}

Securing valuable funds to the company is considered the main task for the finance manager through determining the money needed to finance the capital and the investment activities of the company as well as defining the funds' sources that must be locally and internationally. Thus, studying the capital structure is considered one of the most essential issues in the finance administration. The finance management's decisions are not restricted to determining the ideal capacity of the finance structure but rather controls the money distribution among the company's assets wither they are concrete or circulated so the company can fulfill its working tasks (Zubaidy, 2004).

By reviewing the financial ethics that the researcher accomplished, a difference between the financial structure and the capital structure has been noticed as the financial points to all available funds to be invested (Indian, 2003; Chat, 2016) i.e, the financial structure governs all kinds of finance, debts, ownership, permanent and temporary, long and short term, whereas the capital structure points at the progressive finance of the company which represents the long term loans, excellent shares and normal shares (Almursy \& Al-Laheb, 2006; Hat, 
2016). And the capital structure is highly considered as a part of the financial structure.

\subsection{Sources of Funding}

It is known that the cost of funding and its expected return are considered important elements in which the financial manager depends on while determining the sources of funding. Accordingly, sources of funding are divided into two parts: The first is short-term funding which means the money that the entity receives from the third parties and it is obligated to repay it within a period of no more than one year (Hindi, 2003) (Hat, 2016) . The second part is long term funding sources which is divided into two parts A) The long term funding sources: it include ordinary stocks, preferred stocks, retaining stocks and retaining earnings.

B) Long term external funding sources which include banking long term loans and bonds. Whereas long term funding sources are; 1-common stocks that are considered the ownership of the company's stocks and it contain a nominal value, a market value and a book value. The common stock is issued with nominal value (AlZubaidy, 2004). 2- Preferred stocks: They are considered a source of funding that is characterized by features of combining common stocks and bonds that issued by public stocks companies. It is similar to the characteristics of common stocks as being a guaranteed paying document of ownership, and they have characteristics of bonds as the preferred stocks are obligated to pay a fixed percentage of profits annually, (Al Zubaidy, 2004). Preferred stocks differ from common stocks in the limited percentage of profits. It should not obtain profits that exceed the fixed percentage, (Hindi, 2003). And it doesn't participate in the company's management, but it rather has the priority in distributing the profits and in the value of assets at liquidation (Ross, 1999). The holders of corporate bonds have priority over the holders of preferred stocks in obtaining returns. During reviewing the financial data of the industrial companies by the researcher, no preferred stock is noticed in the capital structure of any industrial company.

3- Retained Earnings: They are considered an available internal funding source for the company (it represent profits earned by the company but the company decided to retain it instead of distributing it to the stockholders .The purpose is to reemploy it in future funding investments (Hindi, 2003). Or It retains part of net profit for possible contingencies that the company might be facing in the future.

Long term external funding sources: 1- corporate bonds: it is a financial instrument hat states the company borrowed certain amount of money and it should be repaid over a maturity date in which it should be written in the body of the bond. And the company should pay the annual interest rate on the due date. Bonds are considered one of long term available funding sources to fund the assets of the companies. It gives the holder the right to obtain the nominal value of the bond on due date and the right to obtain periodic interest rate as a percentage of nominal value (Hindi, 2003). Bonds hold high liquidity to be sold and disposed of in the capital market.

Added to the notice by the researcher in the course of studying, the sample study of the financial data of industrial public stockholding companies, there is inconsiderable number of industrial companies that depend on corporate bonds as a source of long term funding sources. This is due to the following reasons (Abaad, 2003):

1- Lack of public awareness about the importance of bonds as a source of funding among the public as individuals and organizations

2- Lack of credit rating organizations that help investors to make decisions about exporting companies.

3- The bonds market lack of the depth and liquidity.

B) Long-term loans: These are loans the companies obtain by banks and financial organizations. They should be repaid over a certain period of time of more than one year (Hindi 2003). In general, the companies obtain that kind of loans to fund fixed assets or permanent investments or some components of capital (Al Zubaidi, 2004).

The loans will be obtained after the bank's agreement on the borrower company regarding a number of conditions such as (the amount of loan, interest rate (may be fixed or variable or it might be composed of fixed margin or variable margin), repayment period, method of payment, guarantees, the purpose of loan and covenants).

When the amount of loan is relatively massive for the bank, the loan will be offered by groups of banks. It is referred to as syndicated loan.

\section{Previous Studies}

\subsection{Theories of Capital Structure}

The Study of the capital structure is one of the most important topics in financial management. The concern of that field began when Mogiliany and Miller presented the first case study since 1958 in relation of the capital 
structure with the market value of the company. Consequently, gradual studies, searches and theories that deal with the study are followed, and they concluded an abstract for the most important theories such as:

First: the theory of Moedgliani and Miller: Moedgliani and Miller are considered among the first scientists who studied the capital structure. The two scientists presented two articles, one of presented in 1958. It is based on the assumption that there is no income tax. The other presented in 1963 and based on the assumption that there is income tax (Al Hannwi.2006). it consists of two proposals:

A) The market value shall not be affected by the capital structure of any company. That is the market value of the totally funded company in the ownership rights equal to the market value of the company that depends on the ownership and borrowing at the same time (Al Hanwi and Al Abed).

B) The desired return of the stocks of the company that relies on loans is equal to the desired return of the company that depends on the totally ownership rights added to a premium risk that reflects the financial risk of the company (Al Hanwi and others). The second article presented in 1963 is based on the assumption that there is an income tax, and consists two proposals (Brigham,et al,1999): A) the market value of the funded company with ownership rights and loans added to the market value of the totally funded company with the ownership rights + tax saving from dept.

C) The desired return of the stocks of the company that relies on loans equal to the desired return of the company that depends on the totally ownership rights add to premium risk that reflects the financial risk of the company measured by the tax rate.

\subsection{The Agency Cost Theory of Corporate Leverage}

It is one of the capital structure theories developed by Jensen and Meckling in 1976. It arises from the potential conflict of interests between stockholders and managers who manage a company on behalf of the stockholders. However, two problems emerge from agency:

-Adverse selection

-Moral hazard

Jensen and Meckling define the problems of agency as the fixed wages that should be paid to the managers are unable to contribute to settle the conflict of interests between managers and stockholders. (Eieshardt,1985) defined the fixed wages as a stimulation to evade mangers from projects that demand considerable efforts, due to the stabll salary regardless of the efforts or distinguished performance by managers. (Jenson 1986) referred that the conflict of interests between stockholders and managers results from managers' negative investing of the net free cash flow present value project (it achieves return lower than the targeted rate of return of the company). Rather than paying surplus cash flows to stockholders in a form of cash dividends. In purpose of tackle the mentioned phenomenon, the company should obtain loans, and should obliged managers to pay surplus cash flow to pay debts and interests, thus the company may reduce the cash flows available for financial mangers that investing it in projects which unable to achieve positive net present value.

$\mathrm{Wu}, 2004$ referred to the reason of the conflict arises from the investments in different projects by the managers. Even if such projects might not lead to rise of the company value, the important gains for the managers to obtain prestige as managers of large companies.

\subsection{Pecking Order Theory of Corporate Leverage}

The theory refers to the priorities of funding sources for the company as follows:

1- Internal funding by retained earnings and depreciation. In case of the company relying on external funding sources, it turns to the following external sources in order: loans, issuing bonds, callable bonds, issuing preferred stocks and issuing common stocks. Hawawini, Vialkt,1999 referred to such kind of ordering funding sources reflected the concerns of financial managers in the following actions:

- $\quad$ Reduce conflict between stockholders and managers.

- Retain control of company.

- $\quad$ Avoid adverse effect caused by the announcement of new stocks.

Pecking order theory contributes to the fact that most of the profitable companies do not turn to loans due to the surplus cash flow. In contrast, less profitable companies turn to loans but not issuing new stocks, due to costs that associated with bank loans are lower than costs that associated with issuing stocks such as flotation and information costs. And according to pecking order theory loaning is considered the first source of external funding sources and issuing stocks will be the last source that the company depends on after consumption debt 
capacity. Pecking order theory suggests there is no target leverage ratio in contrast to the tradeoff theory of corporate leverage. Pecking order theory is not contributed to the explanation of tax effect, financial distress and the agency cost on the capital structure and it ignore the problem that arising from comprising the liquid assets by the managers as (cash, liquid investment) it contributes as immunity to market discipline.

Pecking order theory predicted the following relationships between financial leverage and determinates:

\begin{tabular}{lc}
\hline Determinate & The relationship between financial leverage and determinate \\
\hline Profitability & - \\
Investment opportunities & $+(--)$ \\
Size & - \\
\hline
\end{tabular}

\subsection{The Tradeoff Theory of Corporate Leverage}

The tradeoff theory suggests that the size of target leverage ratio is accessible by balancing the benefits of loans that represented in tax saving and the cost of loans that represented in costs of financial distress and costs of agency. At optimal size of the debt ratio the benefits of loans are equal to the cost of loans. In the study of Hackbarth, Hennessy and Lelend (2007), the researchers concluded the tradeoff theory is sufficient to explain the capital structure for weak companies for exclusively relying on bank loans in contrast to strong companies that depend on bank loans and capital market with priority dependence on bank loans.

\section{A) Income tax's effects on saving:}

Due to the fact that the company turns to borrowing as one of the funding resources, it shall pay interests for the loans that are considered from a taxing perspective as a productive expense for the income. It shall deduct it from net income of the company before accessing to taxable income thus:

Tax saving $=$ the interest rate on loan* tax rate*amount of loan

Taxes can contribute to reducing the amount of income by the firm and increasing the availability of cash flows (after tax) of the firm.

\section{B) distress costs (Bankruptcy costs)}

Measuring the company's dependency on the excessive debt for funding the operations and investments causes inability to repay the debts and interests particularly if occurred with decreasing or fluctuating net income of the company. Due to that problem, the less profitable firms or the firms suffer from fluctuating income tend to conservative borrowing.

\section{Agency costs:}

The tradeoff theory suggests addressing agency cost that arising from free cash flows, the company shall utilize abundant part of income to repay debts and distribute dividends on stockholders.

The tradeoff theory predicted the following relationships between financial leverage and determinates:

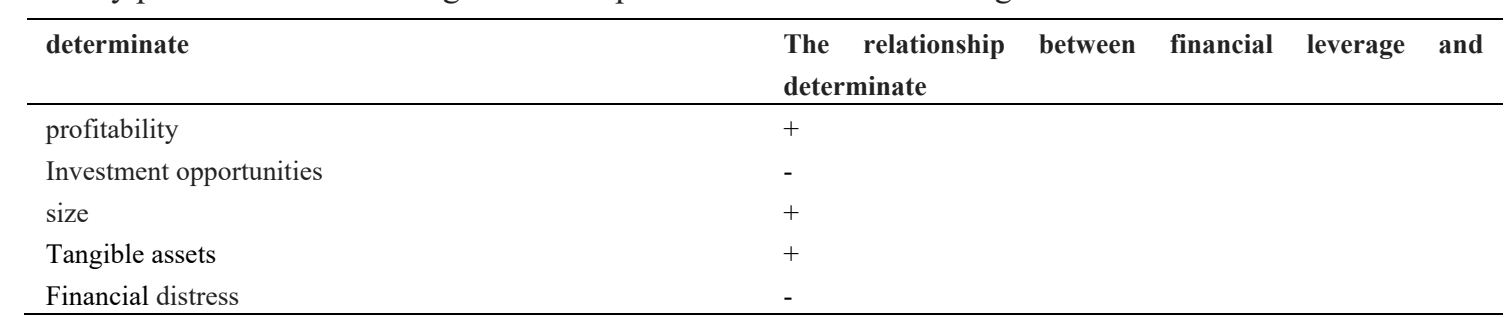

\subsection{Signaling Theory of Corporate Leverage}

Ross founded this theory in 1977. It is based on a symmetric information between well-informed managers and poorly informed outside shareholders about current situations of the company (Meggnison 1997).

Signaling theory is based on the raising the leverage of the company used by the mangers as a positive signal for outside shareholders that the company will gain profit and cash flows in the future.

\subsection{Previous Relevant Studies}

The researcher aims to review previous studies in this chapter which study the capital structure of many developing and developed countries and the different factors that impact of exterminating the capital structure 
whether on local level or international level and utilizing the results of the previous studies to compare with the results of the study hereby. Followed by the most important studies that informed by the researcher such as:

The study of Dinesh Jiasinghani, Kakali Kanjilal, 2017, under the title, Non -linear dynamics of size. Capital structure and profitability: Empirical evidence from Indian manufacturing sector.

The study aimed to know the relationship between the capital structure with the performance in India by Non-liner analysis with the availability of factors that relating to the size,the capital structure and the income of the company . the study based on 1194 public industrial shareholding companies for the period 2005-2014.And it concluded to the most important results that there is a significant impact of the size of the company on the performance and profitability. And the higher financial leverage levels in the capital structure of the company the best profitability. The small companies reduce costs by reducing debts from the capital structure.

The study of Dharmendra Singh 2016, under the title of "A panel Data Analysis of Capital Structure".

Determinates: "An Empirical study of Non- Financial firms in Oman"

The study aimed at determining the factors that determinate the capital structure of non- financial companies in Oman by depending "A panal analysis "and "Fixed And Random Effects" in analyzing data. The study includes a company from Masqat financial market for the period 2011-2015. The study concluded that there is negative relationship between tangible assets, profitability and liquidity with financial leverage. on the other hand, there is positive relationship between small companies and growth opportunities with debt. And there is no significant impact for the tax exemption on the financial leverage for the companies at Oman. The study suggested studying the comparison of the capital structure for companies in developed and developing countries.

The study by Ohood Khasawna in 2006 under the title "Ownership structure And Its Role in determining the Capital Structure at Jordanian public industrial shareholding companies".

The study included 48 industrial and service companies from 2000 to 2003. The study concluded the following results:

(1) There is a positive relationship between the income of the company and the dependence of the company on the borrowing.

(2) There is a positive relationship between the rate of tangible assets with the relying companies on loans.

(3) There is a negative relationship between the liquidity of the company with the dependence of the company on borrowing in funding.

(4) There is negative relationship between the risks of the company with the dependence of the company on borrowing.

(5) There is positive relationship between the seniors shareholders of the company with the dependence of the company on borrowing.

(6) There is negative relationship between the ownership of management of the company with the dependence of the company on borrowing.

The study by Leone Leonida and Aydin Ozekan, Alfosina Lona 2004, entitled "Determinates of financial conservatism": Evidence From Law - Leverage And cash- Rich UK Firms. The study aimed at knowing the determinants of the following companies for the conservative financing policy to the leverage conservatism and cash conservatism (the company shall maintain high cash balances whether in the form of cash or banks deposits or securities investment) the study applied on British companies for the period 1984- 2001 and it used a number of variables to study the relationship between dependence and independence variables such as:

1) Profitability. 2) Fixed assets 3) Size .4) Investment opportunities.5) Ownership structure. The study concluded the following results:

1) There is a negative relationship between debts with cash holding in the company.

2) There is a strong statistical indication that the large firms are less likely to be conservative companies in building the capital structure. Accordingly, the large companies can obtain on outside funding sources in lower expenses and conditions than issues imposed on small companies.

3) The companies with highly opportunities growth maintain high level of cash and low level of debt.

4) There is a positive relationship between the company adoption to the conservative policy and investment opportunities.

5) There is a positive relationship between company adoption to the conservative policy and profitability. 
6) The companies that in greater capital expenditure structure, are less likely to maintain high cash balances.

7) The ownership structure in strong statistical indication in the company adoption to the conservative policy.

The study of Wolfgang Dorbetz and Roger Fix under the title of what are the determinates of capital structure 2005, some evidence for Switzerland.

The study applied on 124 non- financial Swiss companies for the period of 1997-2001. The study aimed at examining the relationship among a number of variables that determinate the capital structure and debts within a frame of two theories of the capital structure theories such as: a) Trade off theory. b) Pecking order theory.

Knowing that the determinate variables of the capital structure and that applied to the study are the following:

1) Tangible assets. 2) Size. 3) Growth opportunities. 4) Profitability. 5) Volatility of cash flow. 6) Non-debt tax shield. 7) Uniqueness. The results of studying as follows:

1) The companies in high investment opportunities apply financial leverage lower than the companies in low high investment opportunities this comparable with Trade off theory and Pecking order Theory.

2) The companies that achieved high level of income use low level of the financial leverage, this comparable with Pecking Order theory and not match with Trade Off theory.

3) There is a noticeable relationship between the availability of tangible assets and volatility of firm earnings and from other hand the financial leverage.

4) The using of financial leverage by Swiss companies is consider low in comparative with European companies that using financial leverage extensively except Germany. $6^{\text {th }}$ : in a study coined by Eugene Fama and kennth French in 2002 entitled: "Testing Trade off and Pecking order Predictions about Dividends and Debts". The study aimed at testing the Trade Off theory and Pecking Order theory in terms of the relationship between profitability and investment opportunities and volatility of firm earnings with the dividends returns. The study applied on 2844 companies for the period 1965- 1997. The study concluded the following results:

1- There is negative relationship between profitability and financial leverage that match Pecking order theory which suggested the companies of high profitability will be in low level of debts. There is a negative relationship between investment opportunities and financial leverage that support Trade off theory and pecking order theory.

2- There is positive relationship between the size of the company and financial leverage. The higher size the lower volatility income. That what Trade Off theory concluded.

In a study by Usha Mitto and French bancal entitled "The Determinates of Capital Structure Choice" "A Survey of European Firms".

The study aimed at knowing the determinants of the companies in 17 European countries compared with the determinants of the American Companies. The survey was sent to the financial managers of the companies of 17 European countries.

In fact the number of the managers are 710 . The survey included the following subjects:

1- The determinate factors of the debt policy.

2- The determinate factors of issuing common stock policy.

3- The determinate factors of issuing common stock policy and foreign debt.

The study concluded many results that relating to the determinate factors of debt policy. What's more, the survey that sent as a study sample includes the following three questions relating to debt policy:

First question: What are the determinant factors of selecting the appropriate debt value for the company? The answers according to the managers are as follows:

1. Financial flexibility. 2.The credit rating of the company. 3. Tax saving of interest rate. 4. Volatility of firm earnings and cash flow. 5. The cost of issuing debt. 6.Expected costs of financial distress and bankruptcy. 7.The level of the debt of other companies in same sector.

Second question: What are the determinant factors of selecting a short-term loan or a long term debt?

The order of determinate factors sorted in accordance with the answers of the managers as follow:

1. The adjustment between the debt maturity and the firm fixed assets. 
2. Companies tend to short-term loans due to the current expectations about the -interest rate on long-term loans will decrease.

3. Companies tend to short-term loans due to the expectations that the credit rating of the company will improve.

The third question: What are other factors that impact on the debt policy of the firm?

According to the answers of the managers, other factors that impact on the debt policy of the company are as follows:

1. Reducing the weighted average cost of the capital.

2. Reducing interest rates.

3. When the market price is undervalued.

4. When the income insufficient for funding the company.

5. The close relationship with banks.

A study by Berndette Aminton and Karen Wruk in 2001 entitled "Financial conservatism Evidence on Capital structure From Low Leverage Firms". The study aimed at testing the phenomenon of conservative policy, by studying the companies that adopted conservative policy in building the capital structure. The study applies on the American companies for the period 1974-1998. It considered the long-term debts ratio to the total assets are less than $20 \%$ in the conservative companies. It used number of variables to compare conservative companies with non- conservative companies in building the capital structure in terms of:

1- Cash flows. 2- Profitability. 3- Cash balances. 4- Research and development expenditures. 5- 5- Debt issuance. 6- Equity issuance. 7- Investment opportunities. 8- Size. 9- Financial distress. The results of the study are as follows:

4- The cash flows and cash balances in the companies that adopted conservative financial policy in building the capital structure are high compared with companies that adopted aggressive financial policy.

5- The companies that adopted aggressive policy in build the capital structure of the company, as a result of decrease the cash flows and cash balances in addition to increase the capital expenses and research and development expenditures of the company.

6- The companies that adopt conservative policy in building the capital structure was a result of the high rates of cash flows and cash balances of the company.

7- The investment opportunities for the conservative companies are higher compared with the aggressive companies.

8- Small companies are more conservative compared with large companies in building the capital structure.

9- The companies that adopted conservative policy less likely to financial distress compared with companies that adopted aggressive policy.

A study by Osama Hayajna in 2001 entitled "the impact of the determinates of the capital structure on performance of the public industrial shareholding companies in Jordan 1990-1999".

The study aimed at knowing the impact of the following factors on the performance of the public industrial shareholding companies in Jordan:

1- Concentration of ownership. 2-Asset-backed securities or (securitization) 3- Financial leverage. 4- Interest tax shield. 5- Company uniqueness. 6- Growth / development. 7-Size of the company.8- Operational risk.

The study was applied on 12 companies and it concluded the following results:

1) There is a statistically significant negative relationship between return on assets and securitization.

2) There is a statistically significant negative relationship between the size of the company and the concentration of ownership. With the return on assets on the other hand.

3) The property rights formed $75 \%$ of the capital structure of the sample study companies. In contrast to the long-term loans that formed only $25 \%$ of the total capital structure of the industrial companies.

In a study by Asli Demirguc, kunt, Varouj Aivazain , Laurace Booth and Vojislav Maksimovice in 1999 under the title of "capital structure in developing countries " 
The researches applied this study on major public shareholding companies in 10 countries such as (India, Pakistan, Thailand, Malaysia, Turkey, Zimbabwe, Mexico, Brazil, Jordan and Korea). For the period 1980- 1990, the study aimed at knowing if the determinants of the capital structure in developing countries are different from those of the capital structure in developed countries by using the following variables: Tax rate, Investment opportunities, size, Securitization ,profitability

The study used three definitions of indebtedness which are:

Total liabilities / total assets, Long-term debts/ Long-term debts + property right at book value ,Long-term debts/ Long-term debts + property right at market value.

The results of the study as follows:

1) The variables that used to explain the capital structure of American and European companies are adequate variables to explain the capital structure of developing countries.

2) There is a negative relation between the size of the company and the indebtedness regardless the concept that used to define the indebtedness.

3) There is a negative relation between the size of the company and the indebtedness for all countries except Mexico, India, Turkey and Zimbabwe. The relation is negative with the mentioned countries.

4) There is a positive relationship between the securitization and the indebtedness for all countries except Brazil, India, Pakistan and Turkey.

5) The size of long term debts of the companies of the developing countries is lower than the size of long term debts of the companies of the developed countries.

6) There is a positive relationship between the investment opportunities and the indebtedness for all countries except South Korea, Pakistan and Zimbabwe. The relation with the mentioned countries is negative.

A study of Shinichi Hiroto in 1998 entitled "Are Corporate Financing Decisions Different in Japan? An Empirical Study on Capital Structure.

The study aimed at knowing to what extent the following factors such as taxes, tangible assets, investment opportunities, profitability, size and income volatility explain the financial leverage of the Japanese companies. The researcher applied study on a sample of industrial and non- industrial companies as follows: In 1977 (407) companies, In1928 (467) companies, In1987 (466) companies, in 1992(546) companies. The statistical analysis was applied per year separately by using the method of small squares. The most important results the study concluded are the following:

1- There is a positive statistical significant relationship between leverage and tangible assets.

2- There is a negative statistical significant relationship between leverage and investment opportunities.

3- There is a negative statistical significant relationship between leverage and profitability.

4- There is a positive statistical significant relationship between leverage and the size.

In a study by Raghuram G. Rajan and luigi Zingalas in 1995 entitled" What do We Know About Capital Structure? Some evidence from international data.

5- The researcher stated, as pervious researches had applied on American companies, that the aim of this study is to know if the determinant factors of the capital structure in America are the same in other countries. Based on that, the study applied on non-financial companies in seven countries such as America, Japan, Germany, France, Italy, England and Canada. They represent $30 \%$ to $70 \%$ of the size of companies that listed within the above mentioned countries. The study used four variables as determinates of the capital structure as (fixed assets, investment opportunities, size of the company and profitability. The study concluded to the following results:

6- There is a positive relationship between indebtedness and tangible assets in all sample study countries.

7- There is a positive relationship between indebtedness and investment opportunities in all countries.

8- There is a positive relationship between indebtedness and the size of the company in all countries except Germany. The relation is negative.

9- There is a positive relationship between indebtedness and the profitability in all countries except Germany.

In a study by Artur Raviv and Minton Harris in 1999 entitled" The Theory of Capital Structure". The aim of the study is to review the previous studies that studied the capital structure. The results of the study related to the capital structure that the financial leverage increases in the following factors:1- Fixed assets. 2- Amortization 
and depreciation. 3- Investment opportunities. 4- Firm size._The financial leverage decreases by the following factors: 1- Volatility of earnings. 2- Advertising expenditures. 3-Probability of bankruptcy. 4-Profitability. 5Uniqueness of product.

\subsection{The Determinant Factors of the Capital Structure in this Study}

The different funding theories assume when the firm determine the capital structure aim at maximize the market value. Based on that, there are multiple researches and studies applied on the capital structure and the determinant factors of the capital structure. After reviewing the previous studies, the researcher found that the following factors consider the most important factors that determine the capital structure such as:

1- Taxes: as the taxes to be paid for debts are considered productive expenses. It is deducted from the taxable income unlike the dividends to stockholders that are not considered productive expenses. it is dividend based on that the companies with non-debt tax shield tend to borrowing (Fama French, 2002)

2- Tangibility : It is a common fact that the financial distress expenditures are depend basically on tangibility .the higher investment of the company in the tangible assets such as land, equipment's, buildings and other tangible assets, the less financial distress in comparative with companies that pre dominantly with intangible fixed assets such as the good will and the patent. Based on that, the financing literature (Trade Off theory), states that there is a positive relationship between the Asset quality and the debt. 3- As the company of big size in comparative with tangible assets, will increase the number of lenders to grant loans for the company. Thus the indebtedness of this company will be big in comparative with the indebtedness of companies with big size of intangible fixed assets. In addition, the availability of fixed assets that presented as securities contribute to reduce the agency cost for lenders Rgajan and zingales (1995). 4- Some researchers notice the importance of tangible assets reduce in the bank oriented countries. (Rgajan \& zingales, 1995). 5- Investment opportunities by reviewing different studies that related to the capital structure, the researcher found the expenditures relating to the bond issuance and to the conflict of interests between stockholders and bondholders are high for the companies with high investment opportunities in contrast to small companies or firms with no investment opportunities. The Trade- Off theory refers that the companies with high level of investment opportunities (Drobez et.2006), the Leverage of it will be low; that what Pecking order theory refer to. The reason is the investment opportunities can assimilate the surplus cash flows in the company, and there is no need for the borrowing to obliged the managers to pay interests for the loans (Farma and French,2002). The leverage is increasing, when the investment opportunities are high in comparative with retained earnings. The leverage is decreasing, when the retained earnings are high in comparative with the investment opportunities. In reviewing the financial literature by the researcher, the researcher discovered that there are multiple financial ratios that can be used as an indication on the investment opportunities such as: the ratio of research and development expenditures/ total assets ( the ratio used for research and development expenditures by the company to increase the investment opportunities for the company (Farma and French, 2002).

(The book value of the assets- nominal value of ownership property+ market value ownership property)/ Book value of the assets

Profitability: the Tradeoff theory suggests that the agency costs, taxes and bankruptcy costs stimulate companies that achieve profitability to increase the financial leverage of it. Due to three following reasons:

1- The expected bankruptcy costs are low with raising profitability.

2- By considering the interests contribute for achieving revenues that motivates companies to fund by loans with interests.

3- Solve the agency problem between the managers and the owner contributes to raising financial leverage. By obliged mangers to pay surplus cash flows in a form of interests (Drobetz etal,).

The Tradeoff theory predicted that there is positive relationship between leverage and profitability. Whereas Pecking order theory suggests that the profitability is mainly related to achieving the revenues by the company. Accordingly, the companies will depend on retained earnings in funding. The theory predicts that there is negative relationship between the leverage

and the profitability, as achieving high profitability by the company includes lower reliance on external sources (Dorbetz etal,2006).

-7 Size: The financial literature suggests that the size of the company considers one of the essential determinates of the capital structure. There are verities in the products of the large companies .And the large companies are less likely to lose (Titman and Wessls, 1988) In contrast to the small companies. In addition, the large companies 
able to obtain loans from banks, financial organizations and the capital market easily in comparative with small companies. Here the researcher suggest that the Trade -off theory predicts the positive relationship between the size of the company and the financial leverage due to what it is called informational asymmetries between the capital market and the firm insiders. According to the purpose of this study and on Titman and Wessles study, the size of the company will be measured by normal logarithm of the sales of the company.8- Financial Distress: it consider one of the essential determinates of the capital structure. It is defined as the state in which the company is unable to repay the liabilities and the assets of the company are low in comparative with the liabilities (Alnajar, 2007) that cause the firm to the clearance. The Trade -off theory suggests that companies will adopt conservative policy, if there are expectations for bearing high expenses, due to the financial distress and according to the equation by Altmam, etal, 2000.

\section{The Results of Statistical Analysis}

The study group consists of 63 industrial companies listed in Amman stock market dated on 31/12/2017. A sample study was taken in accordance to accredited sectorial distribution in Amman stock market. One single leading company has been chosen from each sector. Thus, 15 shareholding companies were chosen to represent all subsectors.

This study aims at clarifying the relation between the dependent variables (indebtedness in its broad meaning) and independent variables (Financial stumbling, size, profitability, interest rate, investment opportunities). It also illustrates the effect of the independent variables on the dependent ones as well as utilizing the following statistical methods that serve this study:

1. Descriptive statistics to analysis data.

2. Multivariable regression analysis.

3. Multivariate test.

4. Value testing.

Descriptive statistic: describe the dependence variable.( the broad concept of the indebtedness)

The following table 1 refers to the descriptive statistic to the dependence variable that represented in the broad concept of the indebtedness.

Table 1. Descriptive statistic

\begin{tabular}{lllll}
\hline The scale $\%$ & 2015 & 2016 & 2017 & Total \\
\hline Mean & $37.2 \%$ & $35.9 \%$ & $33.6 \%$ & $35.6 \%$ \\
The highest value & $75.9 \%$ & $75.9 \%$ & $75.9 \%$ & $75.9 \%$ \\
The less value & $9.5 \%$ & $10.2 \%$ & $5.6 \%$ & $5.6 \%$ \\
Standard Deviation & $21.8 \%$ & $21.2 \%$ & $22.6 \%$ & $21.1 \%$ \\
\hline
\end{tabular}

The average value of the indebtedness $35.6 \%$, and the standard deviation of $21.1 \%$. The highest value recorded in the period is $75.9 \%$, and the lowest value is $5.6 \%$. The value of the standard deviation refers that there is difference in the funding policy that followed by industrial companies in terms of depending on loans. On the other hand, the Average Debt ratios in the company that submitted to the research for the period $(2015,2016$, and 2017) showed relative convergence that refers to the stability of the funding policies during the period of the study.

Description of the independence Variables: The following tables show the descriptive statistic for the independence variables of the study during the period of 2015 to 2017. The table 2 descriptive statistics for the independence variables of the study. 
Table 2. Description of the independence variables

\begin{tabular}{|c|c|c|c|c|c|}
\hline Variable & Scale & 2015 & 2016 & 2017 & Total \\
\hline \multirow{4}{*}{$\begin{array}{l}\text { Company } \\
\text { Profitability }(*)\end{array}$} & Mean & 0.011 & 0.021 & -0.010 & 0.007 \\
\hline & Highest value & 0.098 & 0.112 & 0.131 & 0.131 \\
\hline & Least value & -0.279 & -0.201 & -0.445 & -0.445 \\
\hline & Standard deviation & 0.113 & 0.091 & 0.170 & 0.125 \\
\hline \multirow{3}{*}{ interest rates } & Mean & $9.0 \%$ & $8.8 \%$ & $8.2 \%$ & $8.7 \%$ \\
\hline & Highest value & $9.0 \%$ & $8.8 \%$ & $8.2 \%$ & $9.0 \%$ \\
\hline & Least value & $9.0 \%$ & $8.8 \%$ & $8.2 \%$ & $8.2 \%$ \\
\hline \multirow{5}{*}{ Tangible assets } & Standard deviation & $0.0 \%$ & $0.0 \%$ & $0.0 \%$ & $0.3 \%$ \\
\hline & Mean & $42.6 \%$ & $43.7 \%$ & $43.4 \%$ & $43.2 \%$ \\
\hline & Highest value & $76.5 \%$ & $77.3 \%$ & $74.6 \%$ & $77.3 \%$ \\
\hline & Least value & $21.4 \%$ & $25.7 \%$ & $21.8 \%$ & $21.4 \%$ \\
\hline & Standard deviation & $19.7 \%$ & $17.5 \%$ & $16.6 \%$ & $17.3 \%$ \\
\hline \multirow{4}{*}{$\begin{array}{l}\text { Probability of the } \\
\text { financial distress }\end{array}$} & Mean & $4.6 \%$ & $4.5 \%$ & $5.5 \%$ & $4.9 \%$ \\
\hline & Highest value & $12.9 \%$ & $12.2 \%$ & $20.3 \%$ & $20.3 \%$ \\
\hline & Least value & $0.2 \%$ & $0.1 \%$ & $0.5 \%$ & $0.1 \%$ \\
\hline & Standard deviation & $4.1 \%$ & $3.7 \%$ & $6.1 \%$ & $4.6 \%$ \\
\hline \multirow{3}{*}{ investment opportunities } & Mean & 0.428 & 0.350 & 0.379 & 0.387 \\
\hline & Highest value & 0.776 & 0.803 & 0.749 & 0.803 \\
\hline & Least value & 0.109 & 0.116 & 0.072 & 0.072 \\
\hline \multirow{5}{*}{ company size } & Standard deviation & 0.272 & 0.222 & 0.242 & 0.240 \\
\hline & Mean & 6.433 & 6.285 & 6.339 & 6.355 \\
\hline & Highest value & 7.739 & 7.839 & 7.793 & 7.839 \\
\hline & Least value & 0.000 & 0.000 & 0.000 & 0.000 \\
\hline & Standard deviation & 2.488 & 2.645 & 2.497 & 2.437 \\
\hline
\end{tabular}

According to the table (2) above, the description of the independent variables of the study is as follows:

1- The profitability: the average of the profitability during (2015- 2017) with a value of (0.007) and the standard deviation of $(0.125)$. The highest value recorded during the period is $(0.131)$, whereas the least value is (0.445). It shows a clear indication on the difference ability of the industrial companies in producing profits.

2- Interest cost: the interest rate during (2015-2017) reach to the rate of (8.7\%) and with a standard deviation of $(0.3 \%)$. Whereas the highest value recorded during the period is $(9.0 \%)$.and the least value is $(8.2 \%)$. the rates reflect that there is no sharp volatility in the interest rates in the Jordanian economic environment.

3- The tangible assets: the average of the tangible assets during the period of (2015-2017) in a value of (43.2\%) with a standard deviation of (17.3\%). the highest value that recorded during the period in a value of $(77.3 \%)$. Whereas the least value is $(21.4 \%)$. The difference in the tangible assets average among companies due to the need of companies to that type of the assets. And to the ability of companies to invest with non-tangible assets.

4- Probability of the financial distress: the potential of financing distress during the period (2014-2016) reached to the average of $4.9 \%$ with a standard deviation of $4.6 \%$. The highest value recorded in a value of $21.3 \%$. Whereas the least value in the average of $0.1 \%$.that reflects there is no real threat among the companies included in the financial distress research. And it shows the difference among companies in terms of the probability of occurring distress for the companies with fewer values.

5- The investment opportunities: the average of the investment opportunities reached to 0.387 during the period of (2015-2016) with a standard deviation of (0.240). Whereas the highest value that recorded during the period in a value of $(0.803 \%)$. And the least value was $(0.072)$. The difference among companies due to selecting the sample from All industrial sub-sectors and in different sizes.

6- The size of the company: the average of the size of the company reached to (6.335) during the period (2015-2017) with a standard deviation of (2.437).And the highest value that recorded during the period was 
(7.839). Whereas the least value was (0.000). The difference among companies due to selecting the sample selecting the sample from all industrial sub-sectors and in contrasted sizes.

\subsection{Selecting the Hypothesis of the Study}

The sample study is represented in a group of the public industrial share holding companies during the period (2015-2017). The data of the intended companies collected for the period to the above mentioned from the annual records. Accordingly, the data of the study are considered cross sectional time series. And the pooled regression analysis considers the appropriate model to measure the relationship between variables. After examining the data that is suitable for the model of study and, description the variables of study the hypothesis test presented in this part of the study. The validity of the data verified, by testing the Multicollinearity. All the values of the variance inflation factors were greater than 1 and less than 5 . The phenomenon of auto-correlation calculated by Durbin-Watson Test that not far behind No. (2).that indicates the absence of this phenomenon. The results of the hypothesis test presented as follows:

Table 3. The results of the hypothesis test

\begin{tabular}{llllll}
\hline Variable & Coefficient & Std Error & t-statistic & Prob* & VIF \\
\hline Profitability & 0.182 & 0.016 & 11.091 & 0.000 & 1.302 \\
Interest rates & -3.900 & 1.081 & -3.608 & 0.006 & 1.021 \\
Tangible assets & -0.286 & 0.105 & -2.731 & 0.023 & 1.531 \\
Investment opportunities & 0.067 & 0.010 & 6.827 & 0.000 & 3.082 \\
Prop. Of financial distress & -0.004 & 0.002 & -1.730 & 0.118 & 3.082 \\
Size & -0.088 & 0.026 & -3387 & 0.008 & 1.0978 \\
Regression & -0.002 & 0.001 & -2.017 & 0.075 & \\
R-Squared & 0.911 & & & & \\
Adjusted R-squared & 0.852 & & & & \\
F-statistic & 15.391 & & & & \\
Preb(F- statistic) & 0.000 & & & & \\
Durin-Watson stat & 1.845 & & & & \\
\hline
\end{tabular}

$*$ At the level of significance $0.05 * *$ At the level of significance 0.001 .

The above table reflects that the effect of independent variables was significant. The value is $(F=15.391)$ and the level of significance is (prop=000) which is less than 0,05 . That Indicates the significance of the regression model. Whereas the value $(\mathrm{R}$-squared $=0.911)$ refers to both the independent variables interpret the percentage of 91 from the shifting in the broad concept of the indebtedness rates.

\section{1- The results of the first hypothesis:}

There is no impact on the profitability of the firm by adoption the conservative financing policy in according to the broad concept of the indebtedness in building the capital structure.

The results of the above table showed there is a significant impact on the profitability of the company on the adoption a conservative financing policy in building the capital structure. It clarify that (Prop=0.000,t-statistic11.091,Coeffcient $=0.182$ ). Therefore, null hypothesis shall be rejected and accepted alternative hypothesis that states on : there is the impact on the profitability of the company on the adoption a conservative financing policy in building the capital structure.

2- The results of the second hypothesis: There is no impact on the interest rates of the firm by adoption the conservative financing policy in according to the broad concept of the indebtedness in building the capital structure.

The results of the above table showed there is a significant impact on the interest rates of the company on the adoption a conservative financing policy in building the capital structure. It clarify that (Prop=0.006,t-statistic3.068,Coeffcient $=3.900$ ). Thus null hypothesis shall be rejected .and accepted alternative hypothesis that states on : there is the impact on the interest rates of the company on the adoption a conservative financing policy in building the capital structure

3- The results of the third hypothesis: There is no impact on the tangible assets of the firm by adoption the conservative financing policy in according to the broad concept of the indebtedness in building the capital structure. 
The results of the above table showed there is a significant impact on the tangible assets of the company on the adoption a conservative financing policy in building the capital structure. It clarify that (Prop $=0.023$,t-statistic2.731, Coeffcient $=0.286$ ). Thus, null hypothesis shall be rejected and accepted alternative hypothesis that states on: there is the impact on the tangible assets of the company on the adoption a conservative financing policy in building the capital structure.

4- The results of the fourth hypothesis: There is no impact on the investment opportunities of the firm by adoption the conservative financing policy in according to the broad concept of the indebtedness in building the capital structure.

The results of the above table showed there is a significant impact on the investment opportunities of the company on the adoption a conservative financing policy in building the capital structure. It clarify that (Prop $=0.000$, t-statistic $=6.827$, Coeffcient $=0.067$ ). So, null hypothesis shall be rejected .and accepted alternative hypothesis that states on: there is the impact on the investment opportunities of the company on the adoption a conservative financing policy in building the capital structure.

5- The results of the fifth hypothesis: There is no impact on the financial distress of the firm by adoption the conservative financing policy in according to the broad concept of the indebtedness in building the capital structure.

The results of the above table showed there is a significant impact on the financial distress of the company on the adoption a conservative financing policy in building the capital structure. It clarify that (Prop $=0.118$,t-statistic1.730,Coeffcient $=0.004$ ). Consequently, null hypothesis shall be rejected .and accepted alternative hypothesis that states on : there is the impact on the financial distress of the company on the adoption a conservative financing policy in building the capital structure.

2- The results of the sixth hypothesis: There is no impact on size of the firm by adoption the conservative financing policy in according to the broad concept of the indebtedness in building the capital structure.

The results of the above table showed there is a significant impact on the size of the company on the adoption a conservative financing policy in building the capital structure. It clarify that (Prop $=0.008$,t-statistic3.387,Coeffcient $=0.088$ ). thus null hypothesis shall be rejected .and accepted alternative hypothesis that states on : there is the impact on the size of the company on the adoption a conservative financing policy in building the capital structure.

\section{Conclusions}

1- In comparing the indebtedness of the sample of the study of Jordanian industrial shareholding companies with the companies of the great seven countries and developing countries in accordance to the broad concept of the indebtedness, it noticed the Jordanian industrial companies retain low rates of the indebtedness. The rate of indebtedness reached to $35 \%$ for the Jordanian companies. Whereas in some developing countries such as Korea the indebtedness rate is $73.4 \%$ (Booth,et,al, 1999). And the rate in Brazil is $30.3 \%$. Taking into consideration the number of years of studying. On the other hand, the least value of the indebtedness is in Britain about $54 \%$ (Rajan and Zengales, 1995). Taking into consideration the number of the years of studying. Thus it noticed the Jordanian companies depend on the rights of ownership in funding the current assets and tangible assets .this result comply with Pecking order theory.

2- It is observed there is impact on profitability to the adoption conservative financial policy in accordance with the broad concept of the indebtedness in building the capital structure. This coincide with the study of (Inoa, et al., 2004), the study of (Jaisnghan \& Kanjilal) and with the Tradeoff theory in terms of companies depend on retained earnings in funding. When the profitability of a company increase, it will be less depending on loans as a source of funding. In contrast to the decreasing the profitability of a company, it will motivate the company for borrowing. As the achieved earnings are insufficient to funding assets.

3- It is observed there is impact on the interest rate to the adoption conservative financial policy in accordance with the broad concept of the indebtedness in building the capital structure. That coincides with the Tradeoff theory. As the less interest rate, the higher leverage for the companies. And in case of the cost of loans less than the cost of stocks issuance such as Flotation and information cost, the loans will be the first source of external funding .on the other side, the researcher notice there is short term facilities not associated with interest rate, but it related to the need of the company for funding to distribute returns or to expand.

4- It is noted there is impact on the size of tangible assets to the adoption conservative financial policy in accordance with the broad concept of the indebtedness in building the capital structure. That coincides with the 
study by( Singh , 2016 ),(Fix and Drobets,2005 , (Harris \& Raviv 1991),(Rajan \& Zengles,1995) and the study by (Booth et al., 2001). The researcher noticed, based on the distress theory, the companies with high rate of tangible assets tending to borrow at high rate in comparative with companies with low rates of tangible assets. And it noted that there is exemption to the above mentioned in particular if there is representation to the financial organizations at the board of directors of that companies at which the securities or the tangible assets are not essential in granting loans.

5- It is noted there is impact on the investment opportunities to the adoption conservative financial policy in accordance with the broad concept of the indebtedness in building the capital structure. That conform with the study the study by (Singh, 2016; Minton \& Wruck, 2001; Inoa et al., 2004) and the study by (Dorbetz \& Fix, 2003). The companies with investment opportunities maintain high level of cash.

6- It is noted there is no impact for the financial distress to the adoption conservative financial policy in accordance with the broad concept of the indebtedness in building the capital structure. This is indication that there is no real threat for the intended companies to the financial distress. And it clarify the difference among companies in terms of the possibility of occurring financial distress that conformed with (Minton and Wruck, 2001) . That verifies the notion of the highly depending on loans as a source of funding, the risks of repaying these loans and interests increasing under the volatility of the company returns.

7- It is noted there is significant impact for the size of the company to the adoption conservative financial policy in accordance with the broad concept of the indebtedness in building the capital structure. This conformed to the Tradeoff theories. The higher size of the company. The higher ability for borrowing either therefrom financial organizations or the capital market. And conformed to the study by (Jaisonghan \& Kanjilal.2017), (Minton \& Wruck,2001),(Iona et al., 2004; Harris \& raviv, 1991) and the study by Rajaan and Zinghales (1995).

\section{Recommendations}

Based on the study, the researcher concluded the following:

1- A decreasing of long term loans to the total assets of many public industrial shareholding companies is noted. So, the study recommends Study the underlying causes of this situation.

2- The financial managers suggested studying the capital structure and the determinant factors thereof, that enable them to manage the capital structure of the companies thereof on the scientific basis.

3- Urge companies to the follow conservative financial policy broad concept of the in building the capital structure in case of arising any possibilities of distress.

4- Urge the companies to use Islamic instruments for funding the assets thereof due to its convenient to the economic situation in the market that relating to the profit rates. It shall be confirmed that there is credit rating by international credit agencies in which assist at offering instruments, loans issuing, obtaining bank loans or funding therefrom Islamic banks.

5- Urge companies to use leasing ended ownership or commercial funding in which considers as a long term sources .the study recommends to urge Islamic and commercial banks to activate it to reflect positively on the national economy.

6- Urge companies in tangible assets to obtain funding by Islamic and commercial banks in particular if the costs of borrowing and funding less that costs of stock issuing.

7- Urge companies to obtain funding by Islamic and commercial banks to obtain the advantage of the financial savings with no neglecting the risks of borrowing in terms of inability to repay debts and interests.

8- Studying the determinant factors to the companies that follow the conservative policy in building the capital structure and in maintaining high cash balances and the impact of these policies on the performance of the company.

9- Studying the impact of the existing of financial organizations as broad members at shareholding companies as one of the determinate factors in building the capital structure in particular in relating to interest costs and tangible asstes.

10- It is noticed the lack of studies on the determinate factors for adopting conservative policy to build the capital structure. The researcher recommends studying on different sectors. 


\section{References}

Abbad, J. M. (2003). The importance of using bonds as a substitute of long term bank borrowing and the its impact on Jordanian public shareholding companies and investors. Amman Arab University for Graduate Studies: Jordan.

Althman, E. I. (2000). Predicting Financial Distress of companies: Revising The Z-score and Zeta Models.

Amman Stock Exchange, annual records (2014-2016). Amman, Jordan.

Bancel, F., \& Mitto, U. R. (2001). The determinants of Capital Structure Choice: A survey of European FIRMS.

Berenson, M. L., Levine, D. M., \& Krehbiel, T. C. (2004). Basic Business Statistics. U. S. A: Pearson education international.

Booth, I. V., Varouj, A. D.K., \& Vojislav, M. (2001). Capital Strcture in Developing Countries. Journal of Finance, 56, 87-130.

Bradly, M., Greegg, J., \& Hankim, E. (1984). On the existence of an optima; capital structure, theory and evidence. Journal of Finance, 39, 857-8780

Bradly, M., Gregg, J., \& Hankim, E. (1984). On the existence of an optimal capital structure, theory and evidence. Journal of Finance, 39, 857-878.

Brigham, E. F., Gapenski, L. C., \& Daves, P. R. (1999). Intermediate Financial Management. USA: The Dryden press

Drobetz, W., \& Fix, R. (2005). What are the deteminants of the capital structure? some evidence for Switzerland. Swiss Journal of Economics and Statistics, 14, 171-113.

Drobetz, W., Pebsa, P., \& Wanzenried, G. (2006). Firm characteristics and Dynamic Capital structure adjustment.

Fama, E. F., \& French, K. R. (2202). Testing tradeoff and peacking order predicitions about dividends and debt. Review of Financial Studies, 15, 1-33.

Graham, J. (2000). How Big Are the Tax Benefits of Bebt. Journal of Finance, 55, 191-1942.

Hachbarth, D., Hennessy, C. A., \& Leland, H. F. (2007). Can the trade off theory explain debt structure. Review of Financial Studies, 20, 1389-1428.

Hahajna, O. (2001). The impact of the determine factors on the financial performance fot the public industrial shareholding companies in Jordan(1990-1999). Al albeit University, Mafraq, Jordan.

Hannawi, M. S. A. A., \& Jalal, I. (2006). Financial Management, Input value and making decision. Alexandria, University House.

Harris, M., \& Raviva. (1991). The theory of capital structure. Journal of Japanese and International Economics, 13, 201-229.

Hindi, M. I. (2003). Financial management: Modern analytical introduction. Alexandria, modern Arab office .

Iona, A. L., \& Ozkans, A. (2004). Determinants of financial conservatism: Evidence from Low-Leverage and Cash - Rich Uk Firms.

Jensen, M. C. (1986). Agency costs of free cashflow, copporate finance and takeovers. American Economics Review, 76, 323-339.

Jensen, M. C., \& Meckling, W. H. (1967). Theory of the firm; managerial behavior Agency costs and capital structure. Journal of Financial Theory.

Khasawna, O. (2006). The structure of ownership and the impact thereof in determine the capital structure at public shareholding companies (non - published). Amman Arab University for Graduate Studies: Jordan.

Minton, B. A., \& Wruck, K. H. (2001). Financial conservatism: evidence on capital structure from low leverage firms.

Modigliani, F., \& Miller, M. (1963). Corporation income taxes and the cost of capital, corporate finance and the theory of investment. The American Economic Review, 48(3), 261-297.

Rajan, R., \& Zingaled, L. (1995). What do we know about capital structure? Some evidence from international data. Journal of Finance, 50, 1421-1460.

Ross, S., Westerfield, R. W., \& Jaffe, J. (1999). Corporate Finance. Singapoe: Mcgraw-hill. 
Stulz, R. (1990). Managerial Discretion and Opimal Financing Policies. Journal of Finance, 43, 1-19.

Wu, L. (2004). The Impact of Ownership Structure on Debt financing of Japanese Firms with the Agency Cost of Free Cash Flow.

Zubaidi, H. M. (2004). Advanced Financial Management. AlWaraq for publishing and distribution.

\section{Copyrights}

Copyright for this article is retained by the author(s), with first publication rights granted to the journal.

This is an open-access article distributed under the terms and conditions of the Creative Commons Attribution license (http://creativecommons.org/licenses/by/4.0/). 